Pedagogy: Journal of English Language Teaching

Volume 9, Number 2, December 2021

E-ISSN: 2580-1473 \& P-ISSN: 2338-882X

Published by Institut Agama Islam Negeri Metro

\title{
How does Intensity of Writing Practices Correlate with Argumentative Writing Ability among Indonesian Freshmen Students?
}

\author{
ARTICLE INFO \\ Article history: \\ Received \\ January 25th, 2021 \\ Revised \\ August 11th, 2021 \\ Accepted \\ September $2^{\text {nd }}, 2021$
}

\author{
Yerni \\ Institut Agama Islam Negeri (IAIN) Metro, Indonesia \\ Email: yerni@gmail.com
}


EFL learners in this tertiary level across different disciplines (Noroozi et al., 2018; Luna et al., 2020). In writing argumentative essays, students are required to take a clear position - for example, agree or disagree - on a certain issue, supported with evidence or examples. In this sense, argumentative writing skills delineate students' critical thinking, which involves making a case to withstand a claim and classifying supportive confirmation from multiple sources that connect the claim logically (Hillocks, 2011). This would then need strong argumentation strategies (Mei, 2006; Wingate, 2012) to integrate the pros and cons contributing to generating general conclusions on the topic (Noroozi et al., 2016).

However, argumentative writing is not an easy communication task because it entails complex cognitive and linguistic skills (Nippold \& Ward-Lonergan, 2010) and has been a concern for many educators of EFL students in higher education (Latifi et al., 2020). Teachers often face challenges in teaching argumentative writing such as lack of structure, sound argumentation and solid reasoning (Kellogg \& Whiteford, 2009), lack of knowledge on the characteristics of an argumentative essay (Bacha, 2010), students facing difficulties to putting their knowledge and ideas into writing practice (Noroozi et al., 2016), features of argumentative essays which could be different from an area to another
(Wingate, 2012), leading to students' struggle in writing similar essays for various argumentation tasks in other domains and issues (Wingate, 2012; Noroozi et al., 2018).

In the Indonesian context, such problems and challenges in the teaching of writing are also encountered by students and have been a concern for many teachers in higher education (Toba et al., 2019). Some problems have been found to contribute to the poor quality of writings, particularly argumentative writing essays, of Indonesian students, such as lack of grammatically correct sentences (Rahmatunisa, 2014), the use of appropriate dictions (Abbas \& Herdi, 2018), the influence of the first language (Sukandi, 2013), difficulties in arranging good sentences and paragraphs in English (Mukminin et al., 2015), challenges in developing ideas (Saprina et al., 2021), and lack of confidence and practice in writing (Muamaroh et al., 2020).

These problems, therefore, recommend the presence of additional support for students to write high-quality argumentative essays (Latifi et al., 2020). One of the needed supports in facilitating students to do more writing practices is that acquiring knowledge in language processing is a multifaceted skill that entails much training (DeKeyser, 2010). However, although the vital role of "practice makes perfect" in language learning (Thompson, 2019), there is a paucity of research addressing the 
importance of intensity of writing practice by which students continuously rewrite, revise, and edit their writing to improve it (Wang, 2015), which makes this present study relevant. Therefore, this study fills this gap by investigating the correlation between writing practice intensity and students' argumentative writing skills.

To identify the problems our student participants encountered, we administered pre-research interviews. According to students, the most difficult aspect is putting and organizing the main ideas in sentences and supporting them with convincing details or examples. The other challenge is selecting and using adequate vocabulary under the content of the writing. The correct use of grammar and writing mechanics such as punctuation, spelling and use of capital letters are also found difficult among the students.

The researcher also found that the students' score on argumentative writing competencies was still not in the good category and classically had not reached the expected minimum standards. The competence that had not been achieved optimally was felt by both the students and the teachers. The result of the researchers' observation indicated that argumentative writing skills among the participants were still low. Among all the participants involved, only a small number of students could achieve the expected competencies.
Therefore, based on the problems found in the pre-research stage and the lack of research on examining the link between the intensity of writing practice and students' argumentative essay writing skills, this study is filling in the gap by investigating the correlation of these two variables.

\section{METHOD}

The method used in this research was a descriptive quantitative method with correlation techniques. Following Creswell (2012), this study used static data to measure the level of relationship or correlation between two variables, intensity of writing practice and argumentative writing skills.

This study used two data collection techniques, namely tests and questionnaires. The test was used to collect data related to argumentative writing ability, while the questionnaire was used to obtain data about the intensity of writing practices. The sample was $20 \%$ of the population, and it gained 41 students (19 males and 22 females) from the English language teaching department of an Islamic university in Kota Metro, Lampung province, Indonesia.

\section{RESULTS AND DISCUSSION Description of the Students' Intensity of Practice}

The practice intensity score from instruments consisting of 12 questions was accumulated into a score using ranges 
1-60. Based on the results of a questionnaire distributed and filled in by English Department students related to the intensity of practice, it was found that the lowest score was 30, and the highest score was 59. Based on the data, the average score was 43.66 , while the median was 45.14 , and the standard deviation was 7,61 . Data distribution of practice intensity variables can be seen in the following frequency distribution table.

Table 1 The Distribution of Score Frequency of Practice Intensity (X)

\begin{tabular}{ccccc}
\hline $\begin{array}{c}\mathrm{N} \\
\mathrm{o}\end{array}$ & Interval & $\begin{array}{c}\text { Frequency } \\
\text { absolute }\end{array}$ & $\begin{array}{c}\text { Relative } \\
\text { Frequen } \\
\text { cy }(\%)\end{array}$ & $\begin{array}{l}\text { Cumulative } \\
\text { Frequency } \\
(\%)\end{array}$ \\
\hline 1 & $21-30$ & 1 & 2.44 & 2.44 \\
2 & $31-40$ & 14 & 34.15 & 36.59 \\
3 & $41-50$ & 20 & 48.78 & 85.37 \\
4 & $51-60$ & 6 & 14.63 & 100.00 \\
& & & $\mathbf{1 0 0}$ & \\
& & $\mathbf{4 1}$ & $\mathbf{0 0}$ & \\
\hline
\end{tabular}

Based on the table above, it can be seen that the score of writing practices intensity at the highest interval of 51-60 has six students or $14.63 \%$. This shows that the intensity of training students in the very high category is only $14.63 \%$ of the number of samples studied. The intensity of the writing practices includes the frequency of the writing practices, the duration of the activity, and the student's desire to do writing practices. At the second interval 41 - 50, there were 20 students or $48.78 \%$. It shows that the intensity of the training of students in the high category of students of English Language Education is quite a lot because it reaches $48.78 \%$ of the number of samples studied. The intensity of the writing practices includes the frequency of the writing practices, the duration of the activity, and the student's desire to do writing practices, both at home and at home.

\section{Description of the Students' Argumentative Writing Ability (Y)}

The data of the score of the students' ability to write argumentative texts were obtained from the instrument. The ability to write argumentative texts used a range of values from 1 to 80 . Based on the students' answers when answering questions related to writing argumentative texts, the students got the lowest score of 41.00 and a maximum score of 89.00 . From the obtained data, an average value was 71.80 , median 75.00 , and standard deviation 10.98. The data above can be disclosed in the form of a histogram image as below.

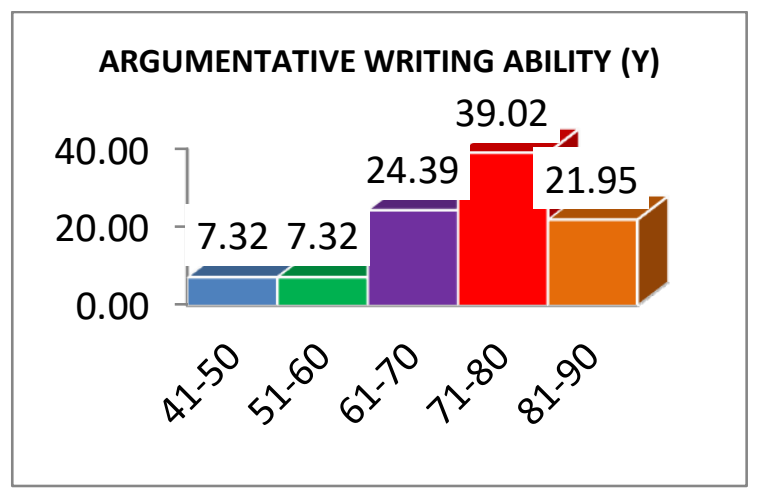

Figure 2. Histogram of Score Frequency of Argumentative Text Writing Ability 
Based on the data above, most students, as many as 16 students or $39.02 \%$, obtained a score within the interval of 71-80. This was parallel to the average score obtained by students, namely 71.80 . The five important aspects of writing, namely content, organization, grammar, vocabulary, and mechanics, become argumentative text writing performance indicators.

The Correlation of Intensity of Practice and Argumentative Text Writing Skills

The relationship between practice intensity and write argumentative writing skill is shown by the regression equation $\hat{Y}=25,583+1,059 \times 2$. The significance test of the regression equation linearity is listed in the following table.

Table 2 ANAVA for Significance Test of Regression $\hat{Y}$ over $\mathrm{X} 2$ with the regression

\begin{tabular}{|c|c|c|c|c|c|c|}
\hline \multirow[b]{2}{*}{$\begin{array}{l}\text { Source of } \\
\text { Variance }\end{array}$} & \multirow[b]{2}{*}{$\mathrm{DF}$} & \multirow[b]{2}{*}{ NQ } & \multirow[b]{2}{*}{ ANS } & \multirow[b]{2}{*}{ Sig. } & \multirow[b]{2}{*}{$\mathrm{F}_{\text {count }}$} & \multirow{2}{*}{$\begin{array}{c}\mathrm{F}_{\text {table }} \\
0,05\end{array}$} \\
\hline & & & & & & \\
\hline Regression & 1 & 2597,305 & 2597,305 & - & 45,523 & 4,10 \\
\hline (a) Rest & 39 & 2225,134 & 57,055 & 0,00 & & \\
\hline Total & 40 & 4822,439 & - & - & & \\
\hline
\end{tabular}

Information:

DF $=$ Degree of Freedom $\mathrm{NQ}=$ Number of Squares ANS $=$ Average Number of Squares

By looking at the results obtained, the regression equation $\hat{Y}=25,583+$ $1,059 \times 2$ shows that every increase in one the intensity of practices score will cause an increase in the score of the ability to write argumentative text of 1,059 at a constant of 25,583 . Thus, the regression equation model $\hat{Y}=25,583+1,059 \times 2$ is statistically significant because Fcount $=$ 45,523> Ftable $=4,10$.

\section{Discussion}

The study hypothesized a significant relationship between the intensity of practice and argumentative text writing skills among the students of the English Education department. Based on the results of calculating the testing of the hypothesis, it turned out that the relationship between the two variables was significant.

When analyzing the students' argumentative text, the researcher found that the results varied greatly. Following (Brown, 2004), the analysis was based on the aspects of writing; namely, content, writing organization, grammar, vocabulary, and writing techniques/mechanisms. The aspects of writing were integrated in complete writing in the form of argumentative text. The following are some of the argumentative texts made by students and comments given by the teacher.

\section{Task 2}

Many people think that the world's problems only matter the young generation as they are the candidates facing them now and in the future. Although a considerable percentage of the public might refer to these hazards as hazards for the young predominantly, yet 
many of these concerns are actually brought into the scene by the old people. The previous generations are those who lived the new developments in science and technology that brought with them pollution, poverty and part of it also possible distinction of many species of plants and animals.

So they raise the alarms for those radical and serious consequences. It is often suggested that old generation are passing by and not interested in what is happening and only the young who gives those alerts considerable thoughts. However, from what we are experiencing now, that many green people are old and work actively to preserve animal rights and fight fiercely against global warming and environmental pollution. This gives us that the present world concerns are a shared interest of both old and new generations. Although many activists on these issues appear in the media and they are from the youth, still and probably equal number from the old follow the same routes.

Actually, no one in this life wants to destroy our planet. every parent is of concern about his offspring lives thereafter, and selfishness does not dominate our thinking at all. One should be aware that such threats are not always discussed or contemplated in the right way by the old or young generation. (264 words)

\section{Grade: 5}

Comments: Though the ideas are relevant and well-argued, cohesion is faulty, and the paragraphing is not logical. Vocabulary is fairly varied and precise. However, though frequent, complex structures are always faulty, with grammatical errors causing some strain for the reader.

\section{Task 2}

There is no doubt that the number of visitors and businessmen and women travelling abroad has been increasing markedly in recent years. However, not surprisingly, understanding the culture of local people brings many benefits to all types of visitors as well as problems for those who do not understand a new culture.

First of all, no sensible person can deny the importance of breaking down barriers between countries. By this, I mean that people from different lands can socialize effectively and relate emotionally regardless of their race and religion if they take time to learn languages and find out about where they are going before they travel. As a result, the tension between people from different backgrounds would be melted.

Another important advantage that needs to be considered is that travellers can broaden their horizons by travelling. In other words, people who travel for business or tourism definitely would gain a lot of information from their host society. Knowing how to behave can help businessmen make lots of money for themselves and for their companies. Undoubtedly business and tourism play a pivotal role in employing of people and reviving the local economy in their own countries and when they travel.

On the other hand, lack of understanding of the culture and traditions of people may lead to misunderstanding and even increased tension between different communities, simply because the background of any society can act as a mirror to reflect the nature, personality and behaviour of people. Certainly, when we know these vital things, we can overcome many difficulties. (262 words)

\section{Grade: 8}

Comments: There are many ideas, well organized into paragraphs and highlighted clearly, despite minor lapses in focus. The wide range of vocabulary 
exhibits flexibility and precision, with only occasional inappropriateness. A variety of sentence structures are used, containing no significant errors.

\section{Task 2}

There is no doubt that age expectancy has increased over the last twenty years. The question matter of dispute. As far as I am concerned, it has a negative effect for a number of reasons.

Some people are of the opinion that this trend should be increased because there might be more experienced workers in society. People will work longer than now. This might have a positive effect on the economy. As we know, these people give taxes to the government. Moreover, if we ask anyone, they are happy to live longer as they devote most of their lives to working. In retirement age, elderly people need comfort and such people to desire to do many things that they did not do before. Thus, the increasing aged population gives hope to the seniors who would like to enjoy their lives. However, I believe that the higher aged population needs higher investment as people in elder age suffer from diseases such as heart disease, stroke, diabetes, Alzheimer's disease. Governments need to invest a colossal sums of money treating such patients. Furthermore people in elder age become more dependent to others as these people need to be prevised by other people. I think nobody likes to live with other people and use the facilities that are not belong to them. Therefore seniors suffer from depression and psychological problems. At the same time if people work longer, there is not promotion for the younger generation because most positions are occupied by the elderly people.

To conclude, I feel that the negative effects on society outweigh the positive effects because of the above reasons. (282 words)

\section{Grade: 6}

Comments: There are plenty of ideas, but paragraphing is not well managed. However, the sentences tend to be clearly linked. The range of vocabulary is adequate for the purpose, as is the variety of sentence structures, but grammatical errors are obtrusive. The best grade is grade 8.

Of the three examples of students' writing above, it can be concluded that the students were generally able to compile ideas well. However, some errors still arose, especially in terms of vocabulary and grammar. This is congruent with some previous studies, which revealed that grammatical errors were frequently found in Indonesian learners' writings (see Madkur, 2013; Hasan \& Munandar, 2018; Hidayat et al., 2020). These two aspects, vocabulary and grammar, are essential parts that must be highly considered in developing learners' writing skills (Andrews et al., 2006; Myhill \& Watson, 2013). To minimize these errors, the intensity of the writing practice is very important to be implemented in order to make the students more aware of their mistakes and, in turn, get used to writing grammatically correct sentences.

\section{The role of Teachers' Feedback in} Developing Students' Writing Skills

It is a widely accepted fact that producing good writing is a complex skill to achieve; therefore, successful writing requires an awareness of the importance of cognitive and motivational factors 
(Hyland, 1998). To this respect, teachers hold a key role in assisting learners in order to be able to produce a good piece of writing. The teachers are expected to provide effective and constructive corrective written feedback to learners' writing (Wicaksono, 2018).

In this study, the teacher of the writing subject gave comments and feedback to students' writings to let students get informed about what they have achieved and which aspects they still need improvement. Written feedback is highly needed by EFL learners in the process of teaching and learning writing (Bostanci \& Çavuşoğlu, 2018). In general, feedback is a continuing teacher-student dialogue that aims to increase students' attentiveness about their strengths and weaknesses and amplify their learning potential (Richards \& Lockhart, 2007; Scott, 2014).

In the context of learning to write, corrective feedback helps students identify errors they make in their writing (Wahyuningsih, 2020). With given feedback, students receive clearer understanding of their learning curve as a basis to develop the capacity to implement acquired skills in future writing situations (Strobl, 2014; Wong et al., 2017), and in turn improve the quality of texts they produce (Crinon \& Marin, 2010).

Regarding the types of feedback for students' writing, the teacher mostly used corrective negating feedback. This kind of feedback let students identify and be aware of their mistakes. It is useful to improve accuracy, but it, as (Ashwell (2000) states, might lure students into becoming more concentrated on surfacelevel errors (focus on form), rather than focusing on making substantial changes to their overall errors (focus on meaning). Therefore, the teacher needs to use constructive affirming suggestions as they are seen as encouraging rather than direct, authoritative corrections. Consequently, students are more likely to be more motivated to practice harder and become self-directed learners (Delante, 2017).

\section{Putting "practice makes perfect" into Practice in Writing Class}

It is popularly known among teachers and learners of English as a foreign language, like other disciplines of knowledge, that to master a language, you need to practice it. But does this influential well-known saying "practice makes perfect" always work in EFL learning context? In this regard, Renandya (2021) emphasizes the importance of the extensiveness or intensity of practices. According to him, it is a process of continuous practices that can contribute to a high degree of mastery of the target skill, allowing us to use the skill effortlessly and automatically. In English language learning, learners must do extensive practices before they can use English fluently for listening, speaking, reading or writing. 
In this study, the intensity of the practice applied to students was intended to stimulate them to improve the quality of learning, particularly in learning to write. In this practice, the students were required to be able to find obstacles that hinder writing skills and find the right way to improve their writing skills. The intensity of this practice was implemented as an effort to familiarize the writing skill so that the trained skills become better. The practices of writing argumentative texts in this study were also inspired by the idea of communicative language teaching approaches, which encourage the importance of exposing students to 'realworld' tasks in classrooms (Dekeyer, 2007).

The students who have a practice intensity score in the good category, it is greatly possible that they have the ability to write argumentative texts in a good category as well. Needless to say, the students who respond positively and do the writing practices seriously are most likely to improve their writing skills and have an impact on the ability to write any kind of text, in this case, argumentative texts. This point of giving opportunities for students to have extensive practices is in line with what Thompson (2019) and Lightbown (2000) highlighted that the role of practice is clearly beneficial and even essential in language learning as it provides the opportunities to use the target language (both receptive and productive skills) and for the thoughtful, effortful practice of difficult linguistic features. Bearing this in mind, the higher the intensity of a student's practice in writing argumentative texts will lead to a better ability to write the argumentative texts. In other words, there is a close connection between the intensity of training and the ability to write argumentative texts of students. In addition, the results of this study indicated that the intensity of practice was one of the most important variables that needed a big attention in order to improve the ability to write argumentative texts.

\section{CONCLUSION}

Despite the significance of writing skills in Indonesian university students' academic achievement, their writing ability is mostly considered low (Delvi Wahyuni et al., 2019; Toba et al., 2019). From the main finding of the present study, it can be concluded that the problem of the low ability in writing argumentative text could be mitigated by allowing the students to have more writing practice. Furthermore, it is evidently shown that there was a robust link between the intensity of practices and writing ability, in this case, writing argumentative text.

Therefore, the teachers of writing subject are expected to increase the intensity of direct practice of writing so that they can figure out where the students' strengths and weaknesses in writing are. The explanation of the 
theories about argumentative writing is, needless to say, highly important, but it could be given integrative when the students produce their writing pieces because writing is a productive skill. If doing so, the students could also specify and focus on what they have to prioritize in terms of learning how to write in English.

\section{RESEARCH IMPLICATION}

The results of this study have implications for teachers to improve their teaching quality to improve the ability to write students' argumentative texts. First, to improve the ability to write argumentative texts, the students need to be encouraged and increase writing interest. The endeavour can be taken through various efforts tailored to students' situation and condition, the university's environment, and the community environment.

Secondly, to improve the ability to write argumentative texts, the students need an effort to increase the quantity and quality of practice intensity. Students who have never done the writing practices will never know their weaknesses and weaknesses in preparing writing and writing applications. The ability to write is an ability that emphasizes motor skills more than the cognitive ability that requires knowledge and habituation. With the intensity of practice, students can be able to convey their ideas and ideas with excellent packaging and in accordance with the criteria of good argumentative text. The intensity of the practice also allows students to be more creative so that they can plan and carry out various variations of writing, including argumentative writing. Increasing the intensity of the writing practice will impact the ability to write the argumentative texts of the students concerned.

\section{ACKNOWLEDGMENT}

The author's sincere gratitude also goes to all participants who have been very helpful and supportive, particularly during the data generation process. She also would like to thank Ahmad Madkur, M.Pd, for proofreading and constructive criticisms of the manuscript.

\section{REFERENCES}

Abbas, M. F. F., \& Herdi, H. (2018). Solving the Students' Problems in Writing Argumentative Essay Through Collaborative Writing Strategy. English Review: Journal of English Education, 7(1), 105. https://doi.org/10.25134/erjee.v7i1.1 499

Andrews, R., Torgerson, C., Beverton, S., Freeman, A., Locke, T., Low, G., Robinson, A., \& Zhu, D. (2006). The effect of grammar teaching on writing development. British Educational Research Journal, 32(1), 39-55. https://doi.org/10.1080/01411920500 401997

Ashwell, T. I. M. (2000). Patterns of Teacher Response to Student Writing 
in a Multiple-Draft Composition Classroom: Is Content Feedback Followed by Form Feedback the Best Method? Journal of Second Language Writing, 9(3), 227-257.

Bacha, N. N. (2010). Teaching the academic argument in a university EFL environment. Journal of English for Academic Purposes, 9(3), 229-241. https://doi.org/10.1016/j.jeap.2010.0 5.001

Bostanci, H. B., \& Çavuşoğlu, Ç. (2018). Pen-and-paper or online? An academic writing course to teachertrainees. Cogent Education, 5(1). https://doi.org/10.1080/2331186X.20 18.1482606

Brown, H. D. (2004). Language Assessment Principles and Classroom Practice. Pearson ESL.

Creswell, J. W. (2012). Educational research: planning, conducting, evaluating, quantitative and qualitative research ((Fourth Edition (ed.)). : Pearson Education Inc.

Crinon, J., \& Marin, B. (2010). The role of peer feedback in learning to write explanatory texts: Why the tutors learn the most. Language Awareness, 19(2), 111-128. https://doi.org/10.1080/09658411003 746604

DeKeyser, R. (2010). Practice for Second Language Learning: Don't Throw out the Baby with the Bathwater. International Journal of English Studies, 10(1), 155. https://doi.org/10.6018/ijes/2010/1

\section{$/ 114021$}

Delante, N. L. (2017). Perceived impact of online written feedback on students' writing and learning: a reflection. Reflective Practice, 18(6), 772-804. https://doi.org/10.1080/14623943.20 17.1351351

Delvi Wahyuni, D. W., Witri Oktavia, W. O., \& Leni Marlina, L. M. (2019). Writing Anxiety among Indonesian EFL College Students: Levels, Causes, and Coping Strategies. Lingua Cultura, 13(1), 67. https://doi.org/10.21512/lc.v13i1.52 39

Hasan, I., \& Munandar, A. (2018). Grammatical Errors Produced by UGM English Department Students. Lexicon, 5(2), 107-114. https://doi.org/10.22146/lexicon.v5i 2.41305

Hidayat, D. N., Fitriyani, N., Alek, A., Septiawan, Y., \& Eviyuliawati, I. (2020). An Investigation into The Grammatical Errors of Students' Writing. Eduvelop: Journal of English Education and Development, 4(1), 9-16. https://doi.org/10.31605/eduvelop.v $4 \mathrm{i} 1.806$

Hillocks, G. (2011). Teaching argument writing, grades 6-12: Supporting claims with relevant evidence and clear reasoning. Heinemann.

Hyland, F. (1998). The impact of teacher written feedback on individual writers. Journal of Second Language Writing, 255-286. 
Kellogg, R. T., \& Whiteford, A. P. (2009). Training advanced writing skills: The case for deliberate practice. Educational Psychologist, 44(4), 250266.

https://doi.org/10.1080/00461520903 213600

Latifi, S., Noroozi, O., \& Talaee, E. (2020). Worked example or scripting? Fostering students' online argumentative peer feedback, essay writing and learning. Interactive Learning Environments, 0(0), 1-15. https://doi.org/10.1080/10494820.20 20.1799032

Lightbown, P. M. (2000). Anniversary article classroom SLA research and second language teaching. Applied Linguistics, 21(4), 431-462. https://doi.org/10.1093/applin/21.4. 431

Luna, M., Villalón, R., Mateos, M., \& Martín, E. (2020). Improving university argumentative writing through online training. Journal of Writing Research, 12(1), 233-262. https:// doi.org/10.17239/JOWR2020.12.01.08

Madkur, A. (2013). Grammatical Analysis on the Abstract of Scientific Writing. Pedagogy: Journal of English Language Teaching, 1(1), 52-67.

Mei, W. S. (2006). Creating a contrastive rhetorical stance: Investigating the strategy of problematization in students' argumentation. RELC Journal, 37(3), 329-353. https://doi.org/10.1177/00336882060 71316
Muamaroh, M., Mukti, V. C., \& Haryanti, D. (2020). The Process and Problems of EFL Learners in English Writing. Ethical Lingua: Journal of Language Teaching and Literature, 7(2), 405-418. https://doi.org/10.30605/25409190.2 15

Mukminin, A., Ali, R. M., \& Ashari, M. J. F. (2015). Voices from within: Student teachers' experiences in English academic writing socialization at one Indonesian teacher training program. Qualitative Report, 20(9), 1394-1407. https://doi.org/10.46743/2160$3715 / 2015.2280$

Myhill, D., \& Watson, A. (2013). The role of grammar in the writing curriculum: A review of the literature. Child Language Teaching and Therapy, 30(1), 41-62. https://doi.org/10.1177/02656590135 14070

Nippold, M. A., \& Ward-Lonergan, J. M. (2010). Argumentative writing in preadolescents: The role of verbal reasoning. Child Language Teaching and Therapy, 26(3), 238-248. https://doi.org/10.1177/02656590093 49979

Noroozi, O., Biemans, H., \& Mulder, M. (2016). Relations between scripted online peer feedback processes and quality of written argumentative essay. Internet and Higher Education, 31, 20-31. https://doi.org/10.1016/j.iheduc.201 6.05 .002

Noroozi, O., Kirschner, P. A., Biemans, H. J. A., \& Mulder, M. (2018). Promoting 
Argumentation Competence: Extending from First- to SecondOrder Scaffolding Through Adaptive Fading. Educational Psychology Review, 30(1), 153-176. https://doi.org/10.1007/s10648-0179400-z

Pirttimaa, R., Takala, M., \& Ladonlahti, T. (2015). Students in higher education with reading and writing difficulties. Education Inquiry, 6(1). https://doi.org/10.3402/edui.v6.242 77

Rahmatunisa, W. (2014). Problems Faced By Indonesian Efl Learners in Writing Argumentative Essay. English Review: Journal of English Education, 3(1), 1-9. http://journal.uniku.ac.id/index.php /ERJEE

Renandya, W. A. (2021). Does practice make perfect?

https://willyrenandya.com/ practicemakes-perfect/

Richards, J. C., \& Lockhart, C. (2007). Reflective teaching in second language classrooms. Cambridge University Press.

Roald, G. M., Wallin, P., Hybertsen, I. D., \& M. Stenøien, J. (2021). Learning from contrasts: first-year students writing themselves into academic literacy. Journal of Further and Higher Education, 45(6), 758-770. https://doi.org/10.1080/0309877X.20 20.1813264

Saprina, C. M., Rosyid, A., \& Suryanti, Y. (2021). Difficulties in Developing Idea Encountered by Students in Writing
Argumentative Essay. Journal of English Language Studies, 5(1).

Scott, S. V. (2014). Practising what we preach: towards a student-centred definition of feedback. Teaching in Higher Education, 19(1), 49-57. https://doi.org/10.1080/13562517.20 13.827639

Strobl, C. (2014). Attitudes towards online feedback on writing: Why students mistrust the learning potential of models. ReCALL, 27(3), 340-357. https://doi.org/10.1017/S095834401 5000099

Sukandi, S. S. (2013). Teaching Writing to Indonesian EFL Learners: Challenges of The "Voice" And "Style" in Adjusting Cross Cultural Communication Skills. Proceedings International Seminar: Language Teaching in Cross Cultural Communication Context, 136-147.

Thompson, C. (2019). Practice makes Perfect? A review of second language teaching methods. The Bulletin of the Graduate School of Josai International University, 22, 55-69.

Toba, R., Noor, W. N., \& Sanu, L. O. (2019). The Current Issues of Indonesian EFL Students' Writing Skills: Ability, Problem, and Reason in Writing Comparison and Contrast Essay. Dinamika Ilmu, 19(1), 57-73. https://doi.org/10.21093/di.v19i1.15 06

Wahyuningsih, S. (2020). the Role of Corrective Feedback on Academic Writing Performance: Efl Students' 
Perceptions. Edulingua: Jurnal Linguistiks Terapan Dan Pendidikan Bahasa Inggris, 7(1), 13-21. https://doi.org/10.34001/edulingua. v7i1.1167

Wang, P. L. (2015). Effects of an automated writing evaluation program: Student experiences and perceptions. Electronic Journal of Foreign Language Teaching, 12(1), 79100.

Wicaksono, W. P. (2018). Types and Frequencies of Written Corrective Feedbacks in Adult ESL Classroom. Indonesian Journal of English Language Studies, 3(2), 17-24.

Wingate, U. (2012). "Argument!" helping students understand what essay writing is about. Journal of English for Academic Purposes, 11(2), 145-154. https://doi.org/10.1016/j.jeap.2011.1 1.001

Wong, C., Delante, N. L., \& Wang, P. (2017). Using PELA to Predict International Business Students' english writing performance with contextualized english writing workshops as intervention program. Journal of University Teaching and Learning Practice, 14(1). https://doi.org/10.53761/1.14.1.8 